\title{
The Effectiveness and the Comparison of e-Learning Lessons Efficiency on the Principles of Digital Photography in Technology of Photography Course
}

\author{
Paramaporn Suksai
}

\begin{abstract}
The purpose of the research was to find out the effectiveness of e-learning lessons and compared lesson efficiency on the Principles of Digital Photography in Technology of Photography Course, using a Modular Object Oriented Dynamic Learning Environment (Moodle) Software and determined learners satisfaction. The sample group was 31 second year of undergraduate students, majoring in Innovation and Educational Technology. The Research tools employed in the study are the following: 1) e-learning lessons on the Principles of Photography; 2) e-learning evaluation form during the learning procedure; 3) learning achievement test; 4) a survey form of student satisfaction. The result of the study show that the average score of content and instructional design was $\mathbf{4 . 3 2}$ which in a high Level, and the average score of production and presentation was 4.37 which also in a high level. The e-learning lessons efficiency E1/E2 was $80.85 / 81.21$ which was above $80 / 80$ set criterion. The students' achievement score in post-test is higher than in pre-test with the statistical significance of 0.05 . The learners' satisfaction toward e-learning lessons has an average score of 4.17. In conclusion, e-learning lessons are on the Principle of Digital Photography could be used in learning.
\end{abstract}

Index Terms-Effectiveness, e-learning lessons, efficiency, digital photography, educational technology.

\section{INTRODUCTION}

Information technology at present has changed rapidly. This causes the application in various affairs both in state and private sectors. Both internal and external educational institutes pay attention and realize its importance of the innovation of structure and strategies of educational management to serve the increasing competition as well as support the change of teaching and learning process. Educational management in the form of e-learning, also known as online learning or distance learning is the use of electronic media via the internet and another meaning, e-learning can be all forms of electronic supported learning and teaching, which are procedural in character and aim to effect the construction of knowledge with reference to individual experience, practice and knowledge of the learner. Information and communication systems, whether networked or not, serve as specific media to implement the learning process [1]. It is a learning approach that is very convenient and flexible. Learners can learn anywhere, anytime with no limitation. They can access the source of information around

Manuscript received November 22, 2014; revised February 3, 2015.

Paramaporn Suksai is with the Faculty of Education of Suan Sunandha Rajabhat University, Thailand (e-mail: Paramaporn.Su@ssru.ac.th). the world seamlessly. They can do activities or do exercises using the services on the network in a variety of formats. Due to the development of knowledge on the Internet, to disseminate and exchange technical knowledge in all areas of your boundaries are possible [2].

According to National Educational Act 1999 section 9 on "Education Technology" significant focus is on the change in the learning process by providing information technology and new innovative studies into the curriculum to expand educational opportunity with quality as well as encourage learners' lifelong learning. It is noted that the management of education via network system in the form of e-learning is in line with the policy of educational reform. It also plays a vital role towards the educational development with quality and efficiency. Furthermore, learning via internet network reduces various limitations as teachers, classrooms and timetables that are defined. It can also cut costs as well as time of creating teaching aids by bringing back the subject contents as well as materials used for making teaching aids [3].

The Department of Innovation and Educational Technology, Faculty of Education, Suan Sunandha Rajabhat University has initiated Technology of Photography course (EDT2105) which is required for the Bachelor of Education course; 2001. It has been improved in line with the changing technology. The scope includes theoretical and practical study of the history and development of technology of photography including camera accessories, the selection of the type of maintenance, principles of digital photography, nature of light, and the composition as well photographic techniques. For this research study, the researcher chose to develop the content of the principles of digital photography as e-learning lesson which is an important topic as it is the basic principles of photography, which was quite large and the student must take a lot of study to understand it. Therefore, the concept of development of e-Learning is learning allowing students to use for the study in order to enhance teaching and learning [4].

\section{OBJECTIVES}

1) To construct as well as find out the efficiency of e-Learning lessons on Principles of Digital Photography in Technology of Photography course (EDT 2105) which is a University course.

2) To compare the achievement post-test and pre-test from learning e-learning on Principles of Digital Photography.

3) To study the satisfaction of the students towards the lessons. 


\section{SCOPE OF LEARNING}

This research is to construct e-learning lessons on Principles of Digital Photography for a second year student in Department of Innovation and Educational Technology, Suan Sunandha Rajabhat University.

\section{A. The Scope of e-Learning Lessons on Principles of Digital Photography Consists of Three Units}

Unit 1: the amount of light in photography

Unit 2: light measuring system and depth of field

Unit 3: composition in photography

\section{B. The Variables in This Study Were}

1) Variables are e-learning lessons on Principles of Digital Photography, distributed through the networks created by Moodle (Modular Object - Oriented Dynamic Learning Environment ).

2) Dependent variables

- The efficiency of e-learning

- The learning achievement of e-learning lessons on Principles of Digital Photography

- The results of the survey for the satisfaction of the students

C. Tools and Applications Used in the Development of e-Learning Lessons on Principles of Digital Photography

The study hypothesis:

1) E-learning lessons on Principles of Digital Photography for a second year student in the field of Innovation and Education Technology, Suan Sunandha Rajabhat University is effectively used in teaching and learning process.

2) Achievement of students' learning is higher than the pre-test at the significance level of 0.05 .

3) Satisfaction of the students after studying the lessons is high.

\section{POPULATION}

The population in this study was 120 students of Department of Innovation and Educational Technology.

The samples used for finding out a quality of instrument included 20 third year students in the fields of Innovation And Educational Technology who enrolled in Technology of Photography Course, with its random placement.

Samples used for finding out efficiency, learning achievement and students' satisfaction were 31 second year students from Department of Innovation and Educational Technology, with its random placement.

\section{INSTRUMENTS}

E-learning lessons on Principles of Digital Photography for the second year students in the Department of Innovation and Educational Technology, Education Faculty, Suan Sunandha Rajabhat University.

Assessment forms of learning activities during each class.

The achievement test on learning consisted achievement test before (Pre-test) and after learning (Post-test), consisting of four alternatives [5].
A satisfaction survey of students towards e-learning lessons on Principles of Digital Photography using the scale estimation (Rating Scale).

\section{DATA COLLECTION}

In data collection, the researcher collected data on e-learning lessons on Principles of Digital Photography. There are steps as follows:

1) Put the sampled students' information into the computer system, explain how to use e-learning courseware and show the structure of the lessons using Moodle 1.9.

2) Samples did pre-test (the achievement test) on Technology of Photography under the topic "Principles of Digital Photography" in the framework of the pre-test (see Fig. 1) and then the program checked the answer and automatically recorded the scores. The researcher collected preliminary data.

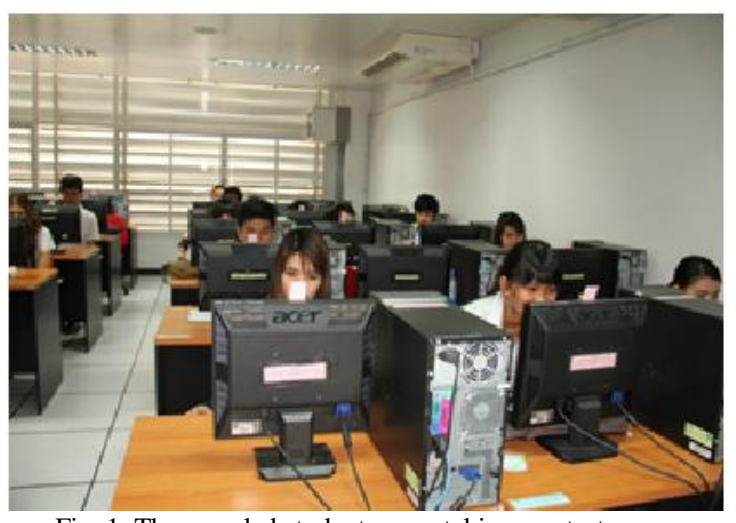

Fig. 1. The sampled students were taking pre-test exam.

3) The samples studied the e-learning contents. They could choose the date, time and place without class. Students could consult or asked for advice from a teacher in regular class hours. They could also post questions on the discussion board or send a message directly to the instructor.

4) During the teaching process, students did exercises of each lesson. The researcher collected data in order to determine the effectiveness of lessons.

5) At the end of each unit, students learned to do the test. In the test after learning, the system checked the answers and automatically recorded the scores. The researcher collected data. The framework of e -Learning lessons is showed in Fig. 2 below:

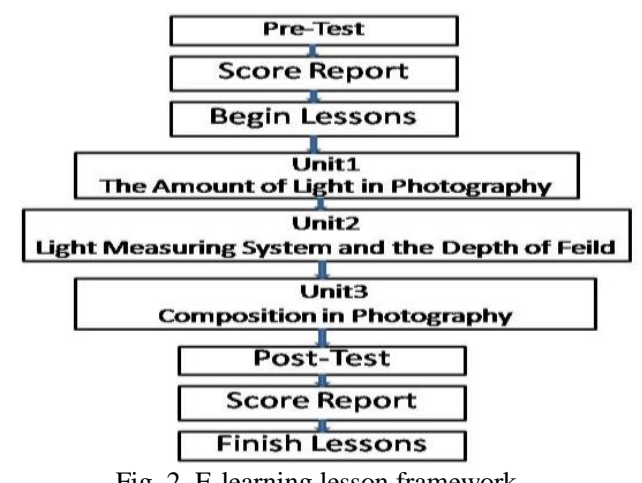

Fig. 2. E-learning lesson framework.

6) The results of the pre-test and post-test were analyzed the 
difference and then determined the effectiveness of e-learning lessons. The scores of both tests on the Internet network system were compared using the statistical t-test.

7) The samples of 31 students answered the questionnaires measuring their satisfaction with the e-learning lessons on Principles of Digital Photography. Questionnaire data were collected for analysis.

\section{THE RESULTS}

1) The efficiency of e-learning lessons about the principles of digital photography from the trial of 31 second year students majoring in Innovation and Educational Technology, revealed in Table I and Table II.

TABLE I: RESULTS OF THE EFFICIENCY OF THE LEARNING PROCESS

\begin{tabular}{cccccc}
\hline $\begin{array}{c}\text { Learning } \\
\text { unit }\end{array}$ & $\begin{array}{c}\text { No. of } \\
\text { learners }\end{array}$ & $\begin{array}{c}\text { Total } \\
\text { scores }\end{array}$ & $\begin{array}{c}\text { Scores } \\
\text { during } \\
\text { learning }\end{array}$ & average & $\begin{array}{c}\text { Process } \\
\text { Effectiveness }\end{array}$ \\
\hline 1 & 31 & 20 & 502 & 16.1 & 80.92 \\
2 & 31 & 20 & 498 & 16.0 & 80.32 \\
3 & 31 & 20 & 504 & 16.25 & 81.29 \\
Total & $\mathbf{A}$ & $\mathbf{6 0}$ & $\mathbf{1 5 0 4}$ & $\mathbf{4 8 . 5 1}$ & $\mathbf{8 0 . 8 5}$ \\
\hline \hline
\end{tabular}

TABLE II: RESULTS OF THE EFFICIENCY OF THE PERFORMANCE

\begin{tabular}{|c|c|c|c|c|c|}
\hline $\begin{array}{c}\text { Learning } \\
\text { unit }\end{array}$ & $\begin{array}{l}\text { No. of } \\
\text { learners }\end{array}$ & $\begin{array}{l}\text { Total } \\
\text { scores }\end{array}$ & $\begin{array}{c}\text { Post } \\
\text { learning } \\
\text { scores } \\
\text { X }\end{array}$ & Average & $\begin{array}{c}\text { Performance } \\
\text { Effectiveness } \\
\varepsilon_{2}\end{array}$ \\
\hline & $\mathrm{N}$ & A & & $\bar{X}$ & \\
\hline 1 & 31 & 15 & 370 & 11.93 & 79.59 \\
\hline 2 & 31 & 15 & 378 & 12.10 & 81.29 \\
\hline 3 & 31 & 15 & 385 & 12.41 & 82.79 \\
\hline Total & $\mathbf{A}$ & 45 & 1133 & 36.54 & 81.21 \\
\hline
\end{tabular}

Table I and Table II show results for the effectiveness of e-learning lessons on Principles of Digital Photography. Effectiveness of lessons during the learning process $\left(E_{1}\right)$ is equal to 80.85 and the performance effectiveness $\left(E_{2}\right)$ is equal to 81.21 , so the effectiveness of the lesson $E_{1} / E_{2}$ is $80.85 /$ 81.21 over the threshold setting is $80 / 80$.

TABLE III: SHOWS THE COMPARISON OF THE ACHIEVEMENT OF E-LEARNING LESSONS ON PRINCIPLES OF DIGITAL PHOTOGRAPHY

\begin{tabular}{lrrrrr}
\hline \hline Learning outcome & $N$ & $\bar{X}$ & SD & $t$-test & $P$ \\
\hline before & 31 & 22.23 & 4.45 & & .00 \\
after & 31 & 36.55 & 3.35 & & \\
\hline \hline
\end{tabular}

2) The result of educational achievement scores before and after e-learning lessons on Principles of Digital Photography in Table III.

From Table III, it tells that the learning achievement of students who learned via e-learning lessons on Principles of
Digital Photography with the achievement test scores after learning process had an average of 36.55, higher than the previous test which had an average of 22.23, which is significantly more important to the statistical significance level of 0.05 .

3) Assessment of learner satisfaction towards the lesson. The researcher found the students' satisfaction after the e-learning lessons on Principles of Digital Photography. A survey of students' satisfaction assessment is presented in Table IV.

TABLE IV: SHOWS ASSESSMENT RESULTS ON STUDENTS' SATISFACTION TOWARDS E-LEARNING LESSONS ON PRINCIPLES OF DIGITAL PHOTOGRAPHY

\begin{tabular}{|c|c|c|c|}
\hline Questionnaire items & $\bar{x}$ & SD & level \\
\hline $\begin{array}{l}\text { 1. E-learning lessons facilitate and make } \\
\text { students learn faster. }\end{array}$ & 4.33 & 0.61 & high \\
\hline $\begin{array}{l}\text { 2. E-learning provide students both } \\
\text { knowledge and entertainment }\end{array}$ & 4.13 & 0.79 & high \\
\hline 3. E-learning lessons are enjoyable. & 4.21 & 0.69 & high \\
\hline $\begin{array}{l}\text { 4. E-learning lessons can be learned } \\
\text { anytime, anywhere. }\end{array}$ & 4.36 & 0.73 & High \\
\hline $\begin{array}{l}\text { 5. Slow learners can learn e-learning } \\
\text { themselves. }\end{array}$ & 4.13 & 0.79 & high \\
\hline $\begin{array}{l}\text { 6. E-learning lessons enable students to } \\
\text { study the subject content in advance. }\end{array}$ & 4.46 & 0.71 & high \\
\hline $\begin{array}{l}\text { 7. Learners who learn through e-Learning } \\
\text { lessons must have high responsibility }\end{array}$ & 3.97 & 0.80 & high \\
\hline $\begin{array}{l}\text { 8. E-learning lessons can be learned by } \\
\text { learners of all levels. }\end{array}$ & 4.15 & 0.77 & high \\
\hline $\begin{array}{l}\text { 9. There should be-e learning lessons on } \\
\text { every subject. }\end{array}$ & 4.46 & 0.71 & high \\
\hline $\begin{array}{l}\text { 10. E-learning can be taught instead of } \\
\text { teachers. }\end{array}$ & 3.82 & 0.87 & high \\
\hline $\begin{array}{l}\text { 11. E-learning lessons provide } \\
\text { opportunity for students to take part in } \\
\text { the learning. }\end{array}$ & 4.10 & 0.74 & high \\
\hline 12. E-learning lessons causes creativity & 4.00 & 0.75 & high \\
\hline Total & 4.17 & 0.76 & high \\
\hline
\end{tabular}

Table IV shows that the students are satisfied with the e-learning lessons on "Principles of Digital Photography". In overall, it is high level on an average of 4.17 and a standard deviation of 0.76 . Most students agreed that e-learning lessons allow students to study content in advance and there should be e-learning lessons in every subject.

\section{DISCUSSION}

The findings have important issues to be discussed below:

1) The efficiency of e-learning lessons on the Principles of Digital Photography for the second year students in Department of Innovation and Educational Technology showed, the $E_{1} / E_{2}$ was $80.85 / 81.21$ which is higher than the $80 / 80$ in line with the research of Nonnapat Tipart and teammates (2010) Creating Computer Lessons on Information Processing Course who studied "the Creation of CAI Electronic Data Processing" and found that the performance of the CAI is effective as / 84.03 83.56 higher than the defined criteria $80 / 80$, indicating that e-learning lessons on "Principles of Digital Photography" has enough efficiency for teaching [6] that was consistent with the research of Chaiwat Waree (2014) who developed online lessons to strengthen the learning process of Master's degree students majoring in Curriculum and Instruction at Suan Sunandha Rajabhat University; to achieve the efficiency criteria of $80 / 80$. 
The sample consisted of 40 university students studying in semester 1, academic year 2012. Data analysis yielded the following results; 83.66/88.29 efficiency of online lessons measured against the criteria [7].

2) The students' achievement deriving from e-learning lessons on "Principles of Digital Photography" for second year students, majoring in Innovation and Educational Technology. The studies showed that their scores on post-test were higher than pre-test at the significance level of 0.05 . E-learning lessons enable learners to learn by themselves, regardless of time and places and students are free to learn.

To achieve the aim of each Learning unit, it is not necessarily similar, or learn together with other students. Various types of learning aids do not cause learners' boredom. Students can receive immediate evaluation in the learning process. Instructors do give them guidance on finding, evaluating the use of multi-media content. These things affect the optimization in the learning of the students which results in higher student achievement, consistent with the findings of Utai Nikom, (2007) The achievement of the students were higher than the previous achievement test at the significance level of 0.05 , which shows that teaching lessons through networking with e-learning as an alternative to teaching and learning process [8].

In terms of students' satisfaction towards e-learning lessons, especially in terms of accessing educational or advanced content, learners are satisfied with the e-learning lessons. The lessons are interesting because they are linked to other learning resources, making it more convenient to study. The students were of the opinion that e-learning lessons should be applied to the learning on other subjects.

\section{SugGestions}

E-learning lessons or instruction through the internet is a result of developments in computer and communications technology (ICT), which makes society into the internet age. It can be seen that the e-learning lessons allow students to take time to learn the lessons as long as they want and often as they like. They meet the needs of learners. Learners can learn regardless of time and place. There is also easy access to the various activities that makes teaching more effective, but a recent study has found that although the teaching and learning through e-learning lessons has many advantages, still, there are several points to consider.

\section{A. In the Device and Networking}

The availability of perfect equipment and network is required. In addition, both teachers and students should have the skills to use computers and networking to make learning successful.

\section{B. Learners' Readiness for Learning through e-Learning Lessons}

With the lessons learned through e-learning is independent and highly flexible, students must have a sense of responsibility and commitment to their learning. They should be honest in the lesson along with the behavior of using social media, including a need to seek new knowledge. In case, the students' learning may fail. Also the areas of learner characteristics, their behaviors, their learning styles that in fluen learners should be studied which is possible by recording their browsing history at their learn time [9].

\section{The Role of the Instructor for Students Taught by e-Learning}

Teachers need to change their roles from knowledge providers to a facilitator, motivating students to learn, providing advice on the activities as well as accessing to resources to learn more. The students should also have an understanding of the factors that are critical to the learning process through the network as well as to make the learning process effective.

\section{Choosing the Right Content with the Lessons of e-Learning}

Only some of the content is suitable to create a lesson, such as e-learning content for knowledge and skills, but may not suit the content that focuses on practical skills. Lessons design should look attractive enough to motivate or attract the students to learn; otherwise it will not achieve the learning objectives.

\section{E. The Preparation of Instructional Environment}

The instructional environment should be well prepared to meet the learner's characteristics, needs, and their learning styles, otherwise learning would not occur .It should be noted that the individual characteristics and needs and learning styles in instruction or teaching learning process are the key component in any effective teaching [10].

According to the study of teaching with e-learning courseware, the researcher found that e-learning is the medium suitable for teaching along with teaching in regular classes, and should be evaluated as well. The conventional method should be used to confirm that learners have actual knowledge of the subject. Also, it was found that e-learning is being used mostly as supplementary learning approach [11].

\section{ACKNOWLEDGMENT}

During conducting this research, I received many advices and materials from many instructors and office staffs at my university which was very helpful. And this research was supported by Suan Sunandha Rajabhat University. I would like to give special thanks to all the experts and students of SSRU who helped and supported this project.

\section{REFERENCES}

[1] D. Tavangarian, M. E. Leypold, K. Nolling, M. Roser, and D. Voigt, "Is e-learning the solution for individual learning," Electronic Journal of e-Learning, vol. 2, no. 2, pp. 273-280, 2004.

[2] T. Laohajaratsang, Designing e-Learning, Bangkok: Arun Printing, 2002.

[3] A. Rattanatirakun, Constructing e-Learning System with Moodle, Bangkok: C Education, 2010.

[4] P. Tiranatanakun, P. Kietkomon, and S. Yampinit, Designing and Creating Computer Lessons for e-Learning Teaching, The Centre of Supplemented Media, Bangkok, 2003.

[5] P. Taweerat, Constructing and Developing Achievement Test, Bangkok: Srinakarintaravirote University, 1987.

[6] N. Tipart et al., "Creating computer lessons on information processing course," presented at Academics Conference, The Faculty of Teachers of Industry and Technology, King Mongkut University of Technology, Thonburi, 2013. 
[7] C. Waree, "A development of online lessons to strengthen the learning process of master's degree students majoring in curriculum and instruction at Suan Sunandha Rajabhat University," World Academy of Science, Engineering and Technology, International Science Index 85, International Journal of Social, Management, Economics and Business Engineering, vol. 8, no. 1, pp. 93-97, 2014.

[8] U. Nikom, "Constructing lessons via Internet network on graphic design for packaging," Thesis, Master of Science, King Mongkut University of Technology, Thonburi, 2007.

[9] S. Kokoty, M. Lal, and S. Sarmar, "E-learning as a research area: An analytical approach," International Journal of Advanced Computer Science and Application, vol. 2, no. 9, pp. 144-148, 2011

[10] L. C. Sarasin, Learning Style Perspective: Impact in the Classroom, Medison, WI: Atwood Publishing, 1999.

[11] T. Laohajaratsang, "E-education in Thailand: Equity, quality and sensitivity for learners and teachers," presented in the International Conference Global Learn 2010 on Learning and Technology, Penang, Malaysia, May 17-18, 2010.

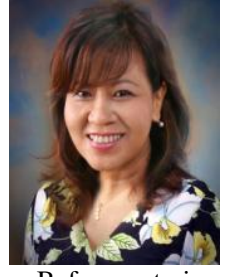

Paramaporn Suksai was born in 1956, Bangkok, Thailand. She went to high school at Triam Udom Suksa School in Bangkok and went on to receive a bachelor's degree in money and banking from Ramkhamhaeng University. After that she went to study abroad and completed her master's in instructional systems technology from Indiana University in the United State in 1984.

Before entering teaching at Suan Sunanda Rajabhat University (the Faculty of Education), she received a Colombo Plan Scholarship for six month audio visual training course at Institution of Education and National University (NUS) in Singapore. For her teaching experiences, She has been teaching in the Department of Innovation and Educational Technology for more than twenty five years and she also served as the department chairman of Innovation and Educational Technology from 2008 to 2013.

Assist. Prof. Paramaporn Suksai has also conducted teachers training programes for in-service teachers all over the country for many years and offered special Photography courses to the communities, as well. 